\title{
Effect of climatic factors during the development periods of flowering and boll formation on the production of Egyptian cotton (Gossypium barbadense L.)
}

\author{
Zakaria M. Sawan $^{\mathrm{a}^{*}}$, Louis I. Hanna ${ }^{\mathrm{b}}$, Willis L. McCuistion ${ }^{\mathrm{c}}$ \\ ${ }^{a}$ Cotton Research Institute, Agricultural Research Center, Ministry of Agriculture \& Land Reclamation, 9 Gamaa St., \\ Dokki 12619, Giza, Egypt \\ bentral Laboratory for Design and Statistical Analysis Research, Agricultural Research Center, Ministry of Agriculture \\ \& Land Reclamation, 9 Gamaa St., Dokki 12619, Giza, Egypt \\ ${ }^{c}$ National Agricultural Research Project, Agricultural Research Center, Ministry of Agriculture and Land Reclamation, \\ 9 Gamaa St., Dokki 12619, Giza, Egypt
}

(Received 22 September 1998; accepted 16 March 1999)

\begin{abstract}
The cotton (Gossypium spp.) plant prematurely sheds its leaves and flowering structures in response to climatic stresses, particularly those of extremes of temperature and water availability. The objective of this study was to investigate the relationship between climatic factors and the production of flowers and bolls. The study focused on four equal 15-day periods during the 60-day development of flowers and bolls (production stage) to study the response of these characters to climatic factors during these periods and to determine the most representative period corresponding to the overall crop pattern. Two uniformity field trials were performed during two successive seasons, 1992 and 1993, at the Agricultural Research Center, Giza, Egypt. The usual agronomic practices of cultivating cotton were followed using the cultivar Giza 75 ( $G$. barbadense L.). From random plant samples the daily numbers of flowers and bolls as well as the percentage of boll retention were recorded. These data were related to the daily air temperature, temperature magnitude, evaporation, soil temperature, sunshine duration, humidity and wind speed. Results indicate that the fourth quarter period of the production stage was the most appropriate and usable time to collect data for determining efficient prediction equations for cotton production in Egypt. Evaporation, humidity and temperature were the principle climatic factors that governed cotton flower and boll production during this quarter. (@ Inra/Elsevier, Paris.)
\end{abstract}

cotton / flower production / boll retention / climatic factors / multiple linear regression

Résumé - Effets des facteurs climatiques durant les périodes de floraison et de formation des fruits sur la production du coton égyptien (Gossypium barbadense L.). La plante de coton (Gossypium spp.) perd prématurément ses

Communicated by Gérard Guyot (Avignon, France)

* Correspondence and reprints

Abeer.Gomaa@ncr.com.eg 
feuilles et ses fleurs en réponse à des conditions climatiques sévères, en particulier, les températures extrêmes et le manque d'eau. Le but de cette étude était de rechercher la relation entre les facteurs climatiques et la production de fleurs et de fruits. L'étude a porté sur quatre périodes égales de $15 \mathrm{j}$ durant la phase de développement des fleurs et des fruits qui dure en tout $60 \mathrm{j}$ (phase de production). Elle a consisté à analyser l'effet des facteurs climatiques durant ces périodes et à déterminer celle qui est la plus représentative de la phase globale de production. Deux essais au champ furent effectués durant deux saisons successives en 1992 et 1993 sur des parcelles homogènes au Centre des Recherches Agricoles de Gizeh en Égypte. Les pratiques agricoles usuelles pour la culture du coton furent suivies en utilisant la variété Gizeh 75 ( $G$. barbadense L.).

À partir d'échantillons constitués de plantes tirées au hasard des comptages quotidiens de fleurs et de fruits ainsi que de fruits noués ont été effectués. Ces données ont été mises en relation avec la température quotidienne de l'air, l'amplitude de température, l'évaporation, la température du sol, la durée d'insolation, l'humidité de l'air et la vitesse du vent. Les résultats obtenus montrent que le quatrième quart de la phase de production est celui qui semble être le plus approprié et le plus utile pour collecter des données destinées à la prévision de la récolte du coton en Égypte. L'évaporation, l'humidité et la température de l'air sont les principaux facteurs climatiques qui affectent la production de fleurs et de fruits de coton pendant le dernier quart de la phase de production. (@ Inra/Elsevier, Paris.)

coton / floraison / nouaison de fruits / facteurs climatiques / régression linéaire multiple

\section{Introduction}

Agronomists and crop production specialists are often unable to determine the effect of various environmental factors on crop growth, development and yield. This results from difficulty in measuring plant responses to different environmental conditions and from the covariance and interactions of environmental factors in the field. A method is needed to provide quantitative information regarding plant responses to weather, soil and management conditions. Modelling and simulation of plant responses to weather and soil conditions could possibly be a useful tool for identifying factors limiting plant growth in complex environments.

The number of flowers produced by a cotton plant is influenced by such factors as soil moisture and fertility, length of the growing season, cultivar, temperature, insects and diseases. When squares, flowers or young bolls are shed and few bolls are developing, vegetative growth is likely to be excessive. The effect of high temperature on cotton flowering and boll retention has been observed for several years. Excessively high temperatures (more than $36{ }^{\circ} \mathrm{C}$ ) can cause flowering buds and bolls to abscise and decrease yield [10, 16]. Causes of boll abscission are often confounded with other factors, such as insect damage, boll load, or water and nutri- tional stresses. The biological causes of reproductive failure at high temperatures are still not known [12], but the consequences are clear and quantifiable. Surely this is an area of research that needs further study, and selection for heat-tolerant types is a desirable objective in plant breeding programmes.

Cool temperatures are a major limitation on cotton productivity $[8,14,19]$. Chilling temperatures $<20^{\circ} \mathrm{C}$ at night hinder boll development [9].

Barker et al. [1] found that sheltering cotton from wind produced larger, earlier fruiting plants, which under proper environmental and management conditions produced higher yields. Dry weather and high temperature during July to September reduced the yield of upland cotton. 'Desi' cotton was affected only by rainfall during July-September. Humidity had no effect on either of the Upland and Desi cottons.

Hodges et al. [12] found that the optimum temperature for cotton stem and leaf growth was $30^{\circ} \mathrm{C}$ and temperature responses of seedling and fruiting cotton were very similar; fruit retention decreased rapidly as the time of exposure to $40{ }^{\circ} \mathrm{C}$ increased. Reddy et al. [17] observed that when cotton cv. DPL 50 plants grown in plant growth chambers were exposed for 70 days to natural light levels with average temperatures of $17.8,18.7,22.7,26.6$ or $30.6{ }^{\circ} \mathrm{C}$, then numbers of squares and bolls pro- 
duced were increased with increased temperature up to $30.6{ }^{\circ} \mathrm{C}$. Miller et al. [13] stated that daily rainfall and temperature data from NOAA were gathered from the 1968-1992 period for each county in Texas Southern High Plains. Rainfall was developed to reflect stored water, growing season, critical growth periods and monthly supplies. Temperature data were used to develop heat units, and high and low temperature thresholds. Multiple regression revealed that in most cases less than $50 \%$ of the yield variation for dryland cotton can be explained by a combination of weather factors. The other $50 \%$ of yield variation is subject to management.

The objective of this study was to investigate the relationship between climatic factors and production of flowers and bolls obtained during the development periods (four periods each of 15 days) of the flowering and boll stage (60 days) of the Egyptian cotton cultivar Giza 75 (Gossypium barbadense L.) under Egyptian conditions. Also, to determine the most representative period corresponding to the overall crop pattern.

\section{Materials and methods}

Two uniform field trials were performed during two consecutive seasons (1992 and 1993) at the Agriculture Research Station, Agricultural Research Center, Ministry of Agriculture, Giza, Egypt, on cotton cultivar Giza 75 on a clay loam soil. The usual agronomic practices were employed, and the normal practices of cultivating cotton in Egypt were followed. Accordingly, the trial was composed of plots, each plot containing 13-15 ridges depending on the slope of the field to facilitate flooding irrigation. Ridges were made according to local practices of $60 \mathrm{~cm}$ apart and $4 \mathrm{~m}$ long. Sowing was carried out on 15 and 23 March for 1992 and 1993 seasons, respectively, in hills $20 \mathrm{~cm}$ apart in the ridges. Hills were thinned to two plants, 6 weeks after planting giving 40 plants/ridge to attain a plant density of 166000 plants/ha. Phosphorus fertilizer was applied at a dose of $54 \mathrm{~kg} \mathrm{P}_{2} \mathrm{O}_{5} / \mathrm{ha}$ as calcium superphosphate $\left(15 \% \mathrm{P}_{2} \mathrm{O}_{5}\right)$, during preparation of the field for cultivation. Potassium fertilizer was applied at a dose of $57 \mathrm{~kg} \mathrm{~K}_{2} \mathrm{O} / \mathrm{ha}$ as potassium sulphate $\left(48 \% \mathrm{~K}_{2} \mathrm{O}\right)$ before the first irrigation. Nitrogen fertilizer was applied at a dose of $144 \mathrm{~kg} \mathrm{~N} / \mathrm{ha}$ as ammonium nitrate with lime $(33.5 \% \mathrm{~N})$ divided into two equal doses, i.e. the 'first dose was after thinning and before the second irrigation and the other dose was before the third irrigation. Pest management was carried out according to the local practice performed at the Experimental Station. Soon after thinning, 261 and 358 uniform plants were randomly selected from the 9 and 11 middle ridges of a plot with 13 and 15 ridges, respectively, during each season. The flowers of selected plants were tagged for use in establishing flowering, fruit-setting and shedding. The flowering season commenced at the opening date of the first flower, and thereafter the opened flowers on all plants were tagged daily until the established date of end of flowering (31 August) which would give opened bolls (50 days of age) at the end of picking (20 October). Each flower was tagged according to its appearance date on the selected plants. In order to calculate fruit analysis, the following were counted from the data collected (used as dependent variables):

i) daily number of tagged flowers per all selected uniform plants;

ii) number of retained bolls within each tagged daily flower per all selected uniform plants at harvest figures 1 and 2);

$$
\begin{aligned}
& \text { iii) percentage boll retention } \\
& =\frac{\text { number of open bolls per day }}{\text { number of tagged flowers per day }} \times 100
\end{aligned}
$$

In the 1992 season, the flowering period was 17 June through 31 August (after this date the flowers would not produce harvested bolls). Recorded dates of irrigation were 15 March (at planting), 8 April, 29 April, 17 May, 31 May, 14 June, 1 July, 16 July and 12 August.

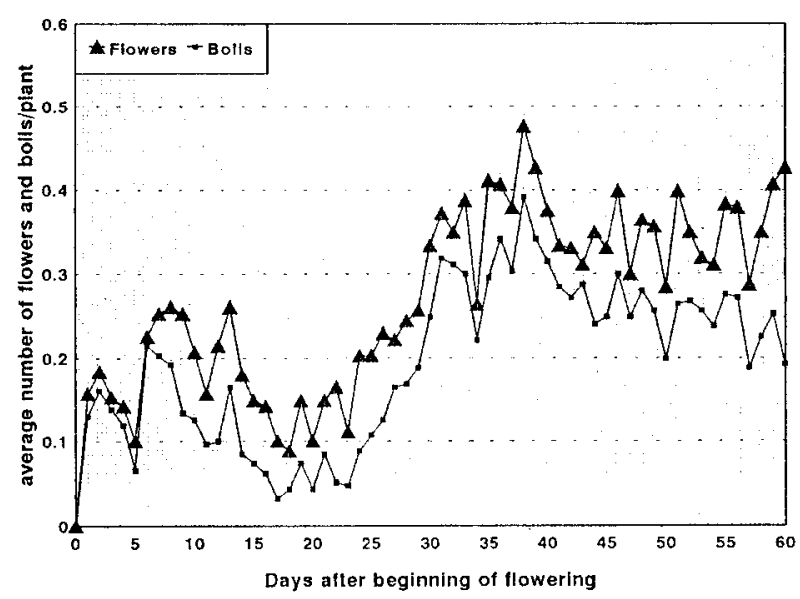

Figure 1. Daily number of flowers and bolls during the first season (sampling size $=261$ plants). 


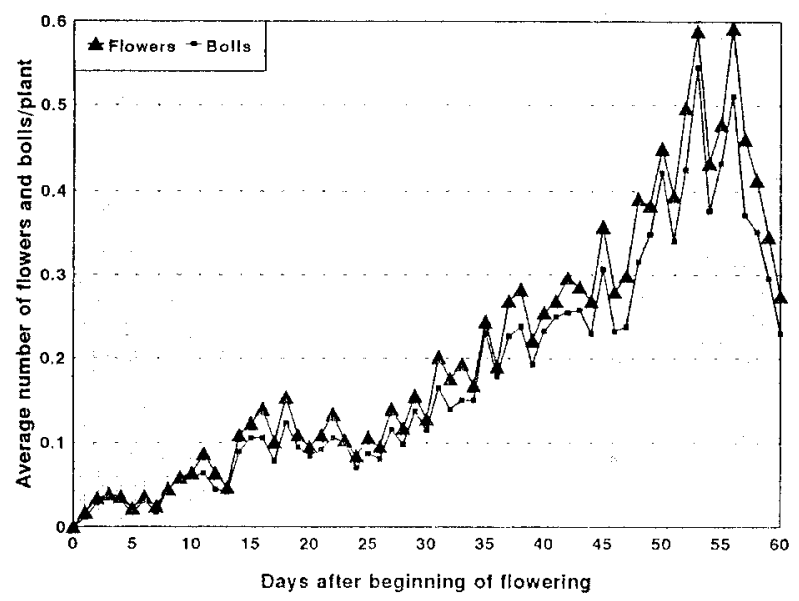

Figure 2. Daily number of flowers and bolls during the second season (sampling size $=358$ plants).

In the 1993 season, the flowering period was 21 June through 31 August. Recorded dates of irrigation were 23 March (planting date), 20 April, 8 May, 22 May, 1 June, 18 June, 3 July, 20 July, 7 August and 28 August (total amount of water required for Egyptian cotton around $6000 \mathrm{~m}^{3} / \mathrm{ha}$ ).

Observations used in the statistical analysis were obtained during the entire production stage of flowering and bolling ( 60 days for each season, 29 June-27 August). The entire production stage was divided into four equivalent quarter periods ( 15 days each) and used for correlation and regression analyses.

Observations used for the statistical computations (independent variables) were daily data of: maximum temperature $\left({ }^{\circ} \mathrm{C}\right)$, minimum temperature $\left({ }^{\circ} \mathrm{C}\right)$, maximum - minimum temperature $\left({ }^{\circ} \mathrm{C}\right)$, evaporation $(\mathrm{mm} / \mathrm{d})$ (Piche evap.), surface soil temperature (grass temperature or green cover temperature) $\left({ }^{\circ} \mathrm{C}\right)$ at 0600 and at 1800 hours, sunshine duration (h/d), maximum humidity $(\%)$, minimum humidity $(\%)$ and wind speed $(\mathrm{m} / \mathrm{s})$.

Statistical analyses were conducted by using SAS [18] general linear models. Daily date of the dependent variables (flowers produced and bolls retained) were regressed as linear functions of the independent variable maximum temperature $\left({ }^{\circ} \mathrm{C}\right)\left(\mathrm{X}_{1}\right)$, minimum temperature $\left({ }^{\circ} \mathrm{C}\right)\left(\mathrm{X}_{2}\right)$, maximum temperature - minimum temperature $\left({ }^{\circ} \mathrm{C}\right)\left(\mathrm{X}_{3}\right)$, evaporation $(\mathrm{mm} / \mathrm{d})\left(\mathrm{X}_{4}\right)$, surface soil tempertaure $\left({ }^{\circ} \mathrm{C}\right)$ at $0600\left(\mathrm{X}_{5}\right)$ and 1800 hours $\left(\mathrm{X}_{6}\right)$, sunshine duration $(\mathrm{h} / \mathrm{d})\left(\mathrm{X}_{7}\right)$, maximum humidity $(\%)\left(\mathrm{X}_{8}\right)$, minimum humidity $(\%)\left(\mathrm{X}_{9}\right)$ and wind speed $(\mathrm{m} / \mathrm{s})\left(\mathrm{X}_{10}\right)$.
Simple correlation between the initial group of independent variables and the corresponding dependent variables were calculated for each season and for the combined data of the two seasons. The significance of the simple correlation at a probability level not exceeding 0.15 was tested to determine the important factors affecting the dependent variables. The 0.15 level of significance was used according to Cady and Allen [4], as they mentioned that "It is believed that the prevailing practice is to use the larger significance levels in variable selection so that a so-called important variable would not be eliminated from the equation. This practice for including a large number of variables in an equation is based, in part, on the feeling that extra variables can not do any harm".

Multiple linear regression equations, containing selected predictive variables, were computed and coefficients of multiple determination $\left(\mathrm{R}^{2}\right)$ were calculated to measure the success of the regression models in explaining the variation in the data, according to Draper and Smith [5].

\section{Results and discussion}

Independent variables (climatic factors), their range and mean values for the two seasons, and during the four periods of flower and boll production stage are listed in table $I$.

Figures 3 and 4 indicate the number of total flowers and bolls produced during the four quarters of the production period for all randomly selected plants. Both flower number and boll production show a higher value in the third and fourth quarters of the production stage, accounting for about $70 \%$ of total production during the first season and about $80 \%$ of the total in the second season.

Simple linear correlation between the climatic factors and the studied characteristics, i.e. flower, boll production and boll retention ratio, were calculated based on quarters of the production stage for each season. Significant relationships $(\leq 0.15)$ are shown in tables $I I$ and $I I I$. Examining these tables, it is clear that the fourth quarter of the production stage consistently exhibited the highest $\mathrm{R}^{2}$ values regardless of the second quarter for boll retention ratio; however, fewer data pairs were used ( $n=30$ for combined data of the fourth quar- 
Table I. Range and mean value of the independent variables (climatic factors) during the four periods of flower and boll production stage.

\begin{tabular}{|c|c|c|c|c|c|c|c|c|c|}
\hline \multirow{2}{*}{$\begin{array}{l}\text { Climatic } \\
\text { factors }\end{array}$} & & \multicolumn{2}{|c|}{ First period } & \multicolumn{2}{|c|}{ Second period } & \multicolumn{2}{|c|}{ Third period } & \multicolumn{2}{|c|}{ Fourth period } \\
\hline & & Range & Mean & Range & Mean & Range & Mean & Range & Mean \\
\hline \multicolumn{10}{|c|}{ First season } \\
\hline Max temp. $\left({ }^{\circ} \mathrm{C}\right)$ & $\left(\mathrm{X}_{1}\right)$ & $31.0-37.3$ & 33.7 & $33.0-37.3$ & 34.7 & $32.4-37.2$ & 34.5 & $32.0-38.4$ & 33.8 \\
\hline Min temp. $\left({ }^{\circ} \mathrm{C}\right)$ & $\left(X_{2}\right)$ & $18.6-23.5$ & 21.4 & $20.6-23.5$ & 22.3 & $18.9-24.4$ & 21.6 & $19.6-23.8$ & 21.8 \\
\hline $\operatorname{Max}-\operatorname{Min}\left({ }^{\circ} \mathrm{C}\right)$ & $\left(\mathrm{X}_{3}^{-}\right)$ & $9.4-14.8$ & 12.3 & $9.8-15.6$ & 12.4 & $9.7-18.3$ & 12.9 & $9.5-14.6$ & 12.0 \\
\hline Evapor. (mm/d) & $\left(X_{4}\right)$ & $10.2-15.2$ & 11.7 & $8.0-13.2$ & 10.1 & $7.6-11.2$ & 9.1 & $7.7-11.1$ & 9.2 \\
\hline 0600 hours temp. $\left({ }^{\circ} \mathrm{C}\right)$ & $\left(X_{5}^{+}\right)$ & $14.2-19.9$ & 16.8 & $15.8-21.5$ & 18.9 & $13.9-21.1$ & 17.4 & $15.4-20.8$ & 18.0 \\
\hline 1800 hours temp. $\left({ }^{\circ} \mathrm{C}\right)$ & $\left(X_{6}\right)$ & $22.0-25.2$ & 23.8 & $22.2-27.0$ & 24.2 & $19.6-25.6$ & 24.1 & $21.8-26.0$ & 23.9 \\
\hline Sunshine $(\mathrm{h} / \mathrm{d})$ & $\left(X_{7}\right)$ & $11.4-12.9$ & 12.4 & $10.4-12.4$ & 11.5 & $10.5-12.4$ & 11.6 & $9.9-12.2$ & 11.4 \\
\hline Max humidity (\%) & $\left(X_{8}\right)$ & $62-88$ & 80.7 & $84-94$ & 88.4 & $85-96$ & 89.9 & $76-96$ & 87.4 \\
\hline Min humidity (\%) & $\left(X_{9}^{\circ}\right)$ & $21-37$ & 28.2 & $22-43$ & 31.4 & $17-42$ & 29.9 & $24-45$ & 34.0 \\
\hline \multicolumn{10}{|c|}{ Second season } \\
\hline Max temp. $\left({ }^{\circ} \mathrm{C}\right)$ & $\left(X_{1}\right)$ & $31.4-38.8$ & 35.5 & $31.4-35.5$ & 33.4 & $32.6-37.9$ & 34.4 & $30.6-34.6$ & 32.8 \\
\hline Min temp. $\left({ }^{\circ} \mathrm{C}\right)$ & $\left(\mathrm{X}_{2}\right)$ & $20.1-23.4$ & 21.3 & $19.6-23.1$ & 21.7 & $18.4-24.3$ & 22.3 & $18.6-23.9$ & 21.7 \\
\hline $\operatorname{Max}-\operatorname{Min}\left({ }^{\circ} \mathrm{C}\right)$ & $\left(\mathrm{X}_{3}\right)$ & $9.4-17.6$ & 14.2 & $10.1-15.0$ & 11.7 & $9.6-17.0$ & 12.1 & $8.5-12.6$ & 11.0 \\
\hline Evapor. (mm/d) & $\left(X_{4}\right)$ & $5.9-9.8$ & 7.5 & $5.0-7.0$ & 6.0 & $4.3-7.1$ & 5.6 & $4.1-6.1$ & 4.9 \\
\hline 0600 hours temp. $\left({ }^{\circ} \mathrm{C}\right)$ & $\left(\mathrm{X}_{5}^{+}\right)$ & $15.5-20.4$ & 17.5 & $15.2-21.4$ & 18.4 & $12.9-22.4$ & 18.7 & $13.3-21.0$ & 17.5 \\
\hline 1800 hours temp. $\left({ }^{\circ} \mathrm{C}\right)$ & $\left(X_{6}\right)$ & $22.8-26.5$ & 24.4 & $22.2-26.5$ & 24.2 & $22.9-27.4$ & 24.4 & $20.6-25.8$ & 23.6 \\
\hline Sunshine $(\mathrm{h} / \mathrm{d})$ & $\left(\mathrm{X}_{7}\right)$ & $11.2-13.0$ & 12.4 & $10.9-12.6$ & 11.9 & $10.6-12.4$ & 11.6 & $10.3-12.3$ & 11.5 \\
\hline Max humidity (\%) & $\left(\mathrm{X}_{8}\right)$ & $62-83$ & 71.7 & $51-82$ & 72.8 & $59-81$ & 74.7 & $64-84$ & 73.3 \\
\hline Min humidity (\%) & $\left(X_{9}\right)$ & $23-44$ & 33.1 & $32-50$ & 41.3 & $29-51$ & 39.9 & $37-52$ & 44.7 \\
\hline Windspeed $(\mathrm{m} / \mathrm{s})$ & $\left(X_{10}^{9}\right)$ & $2.8-6.8$ & 5.1 & $3.4-6.6$ & 4.5 & $2.2-7.8$ & 4.4 & $3.4-5.8$ & 4.5 \\
\hline
\end{tabular}

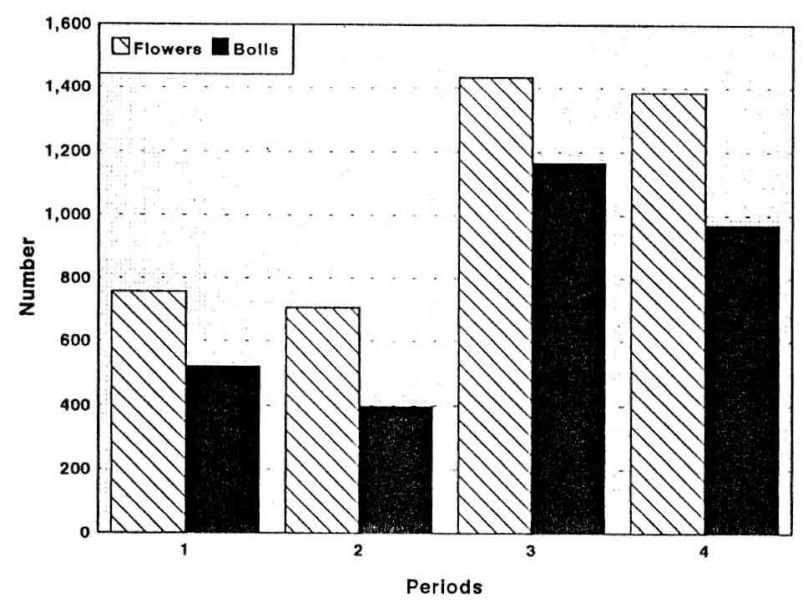

Figure 3. Number of flowers and bolls produced during periods of the production stage in the first season.

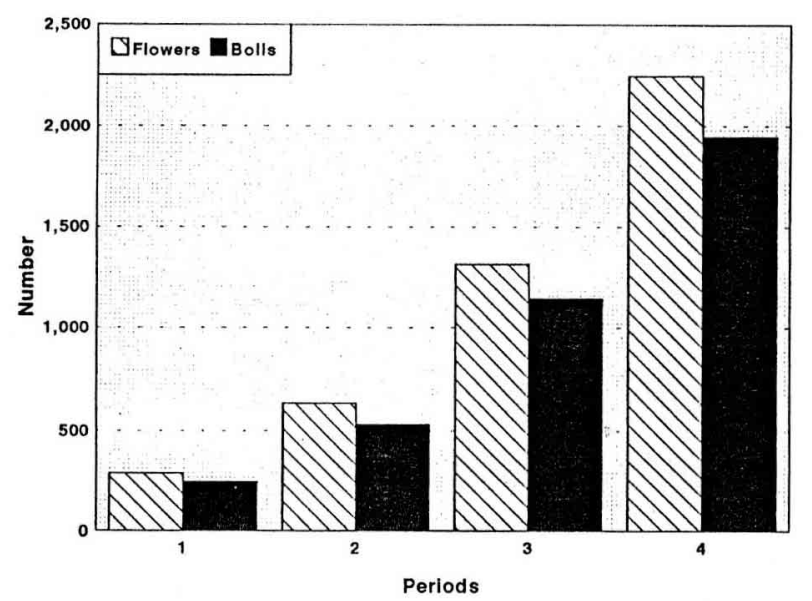

Figure 4. Number of flowers and bolls produced during periods of the production stage in the second season. 
Table II. Significant simple correlation values between the climatic factors and flower, boll production and boll retention ratio due to quarters of production stage.

\begin{tabular}{|c|c|c|c|c|c|c|c|c|c|c|c|c|}
\hline \multirow{2}{*}{ Climatic factors } & \multicolumn{4}{|c|}{ Flower } & \multicolumn{4}{|c|}{ Boll } & \multicolumn{4}{|c|}{ Ratio: Bolls/Flowers (100) } \\
\hline & $1 \mathrm{st}$ & $2 n d$ & $3 \mathrm{rd}$ & 4 th & $1 \mathrm{st}$ & $2 \mathrm{nd}$ & $3 \mathrm{rd}$ & 4th & $1 \mathrm{st}$ & 2nd & $3 \mathrm{rd}$ & 4th \\
\hline
\end{tabular}

First season $(n$ by quarter $=15)$

\begin{tabular}{|c|c|c|c|c|c|c|c|c|c|c|c|c|c|}
\hline ax temp. $\left({ }^{\circ} \mathrm{C}\right)$ & $\left(X_{1}\right)$ & n.s. & n.s. & n.s. & n.s. & nis. & n. & n.S. & n.s. & n.s. & n.s. & n.s. & n.s. \\
\hline in temp. $\left({ }^{\circ} \mathrm{C}\right)$ & $\left(X_{2}\right)$ & $0.516^{*}$ & $0.607^{*}$ & s. & n.s. & $0.561^{*}$ & $0.638^{* 3}$ & n.s. & n.s. & n.s. & $0.680^{* *}$ & n.s. & n.s. \\
\hline$n\left({ }^{\circ} \mathrm{C}\right)$ & $\left(\mathrm{X}_{3}^{-}\right)$ & n.s. & n.s. & $0.538^{*}$ & n.s. & n.s. & n.s. & $0.494^{*}$ & n.s. & $0.515^{*}$ & n.s. & n.s. & n.s. \\
\hline d) & $\left(X_{4}^{3}\right)$ & $0.512^{*}$ & $-0.598^{*}$ & n.s. & $0.424^{++}$ & $0.397^{+}$ & $-0.500^{*}$ & $-0.321^{+}$ & n.s. & n.s. & $-0.387^{+}$ & $-0.287^{+}$ & + n.s. \\
\hline C) & $\left(X_{5}^{+}\right)$ & $-0.352^{+}$ & $0.534^{*}$ & $-0.358^{+}$ & $0.301^{+}$ & $0.402^{+}$ & $0.516^{*}$ & $-0.441^{++}$ & n.s. & n.s. & $0.440^{++}$ & n.s. & $2^{+}$ \\
\hline 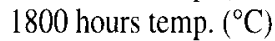 & $\left(X_{6}\right)$ & n.s. & n.s. & n.s. & n.s. & n.s. & n.s. & n.s. & n.s. & n.s. & n.s. & n.s. & n.s. \\
\hline & $(\mathrm{X}$ & n.s. & n.s. & $0.346^{+}$ & n.s & n. & n. & & $0.430^{++}$ & 11. & $\mathrm{n}$. & n.s. & $0.480^{*}$ \\
\hline$(C)$ & Y & $-0.316^{+}$ & $-0.260^{+}$ & $0.461^{++}$ & $0.283^{+}$ & n.s. & & $0.410^{++}$ & n.s. & $0.389^{+}$ & n. & n.s. & $-0.322^{+}$ \\
\hline in humidity $(\%)$ & $\mathrm{Y}^{8}$ & n.s. & $0.309^{+}$ & $-0.436^{++}$ & n.s. & n.s. & $0.436^{++}$ & $-0.316^{++}$ & n.s. & $-0.473^{++}$ & $+0.527^{*}$ & n.s. & n.s. \\
\hline
\end{tabular}

Second season $(n$ by quarter $=15)$

\begin{tabular}{|c|c|c|c|c|c|c|c|c|c|c|c|c|c|}
\hline Max temp. $\left({ }^{\circ} \mathrm{C}\right)$ & $\left(X_{1}\right)$ & n.s. & n.s. & n.s. & $-0.730^{* *}$ & n.s. & n.s. & n.s. & $-0.654^{* *}$ & n.s. & n.s. & $0.407^{++}$ & + n.s. \\
\hline Min temp. $\left({ }^{\circ} \mathrm{C}\right)$ & $\left(X_{2}\right)$ & n.s. & n.s. & n.s. & $-0.451^{++}$ & n.s. & n.s. & n.s. & $-0.343^{+}$ & n.s. & n.s. & n.s. & n.s. \\
\hline $\operatorname{Max}-\operatorname{Min}\left({ }^{\circ} \mathrm{C}\right)$ & $\left(X_{3}^{-}\right)$ & n.s. & n.s. & $0.598^{*}$ & n.s. & n.s. & n.s. & $0.536^{*}$ & n.s. & $0.456^{++}$ & $-0.416^{++}$ & $+\quad$ n.s. & n.s. \\
\hline Evapor. $(\mathrm{mm} / \mathrm{d})$ & $\left(X_{4}\right)$ & n.s. & n.s. & $0.640^{* *}$ & n.s. & n.s. & n.s. & $0.580^{*}$ & n.s. & n.s. & $-0.318^{+}$ & n.s. & n.s. \\
\hline 0600 hours temp. $\left({ }^{\circ} \mathrm{C}\right)$ & $\left(X_{5}\right)$ & $-0.397^{+}$ & $-0.301^{+}$ & $-0.407^{++}$ & $-0.506^{*}$ & $-0.380^{+}$ & $-0.323^{+}$ & $-0.332^{+}$ & ${ }^{+}-0.426^{++}$ & n.s. & n.s. & $0.283^{+}$ & + n.s. \\
\hline 1800 hours temp. $\left({ }^{\circ} \mathrm{C}\right)$ & $\left(X_{6}\right)$ & n.s. & $-0.440^{++}$ & n.s. & $-0.656^{* *}$ & n.s. & $-0.410^{++}$ & n.s. & $-0.582^{*}$ & $-0.626^{* *}$ & n.s. & n.s. & n.s. \\
\hline Sunshine $(\mathrm{h} / \mathrm{d})$ & $\left(X_{7}\right)$ & $0.362^{+}$ & n.s. & n.s. & n.s. & $0.340^{+}$ & $0.308^{+}$ & $0.354^{+}$ & n.s. & n.s. & $0.409^{++}$ & n.s. & n.s. \\
\hline Max humidity (\%) & $\left(X_{8}\right)$ & $-0.523^{*}$ & $0.424^{++}$ & $-0.587^{*}$ & n.s. & $-0.530^{*}$ & $0.431^{++}$ & $-0.586^{*}$ & n.s. & n.s. & n.s. & n.s. & n.s. \\
\hline Min humitity (\%) & $\left(X_{9}\right)$ & n.s. & n.s. & $-0.585^{*}$ & $0.639^{* *}$ & n.s. & n.s. & $-0.517^{*}$ & * $0.652^{* *}$ & n.s. & n.s. & n.s. & $420^{++}$ \\
\hline
\end{tabular}

n.s. Means simple correlation coefficient is not significant at the 0.15 alpha level of significance.

** $\quad$ Significant at $1 \%$ probability level $;{ }^{*}$ significant at $5 \%$ probability level.

++ Significant at $10 \%$ probability level; ${ }^{+}$significant at $15 \%$ probability level.

$n \quad$ Number of data pairs used in calculation.

Wind speed did not show a significant effect upon the studied production variables.

Table III. Significant simple correlation values between the climatic factors and flower and boll production, and boll retention ratio due to quarter periods of production stage for the combined data of the two seasons $(n=30)$.

\begin{tabular}{|c|c|c|c|c|c|c|c|c|c|c|c|c|c|}
\hline \multirow{2}{*}{ Climatic factors } & & \multicolumn{4}{|c|}{ Flower } & \multicolumn{4}{|c|}{ Boll } & \multicolumn{4}{|c|}{ Ratio: Bolls/Flowers (100) } \\
\hline & & lst & 2 nd & $3 \mathrm{rd}$ & 4th & lst & 2nd & $3 r d$ & 4th & $1 \mathrm{st}$ & 2nd & $3 r d$ & 4 th \\
\hline Max temp. $\left({ }^{\circ} \mathrm{C}\right)$ & $\left(X_{1}\right)$ & n.s. & n.s. & $0.29^{+}$ & $-0.48^{* * *}$ & n.s. & n.s. & $0.38^{++}$ & $-0.47^{* *}$ & $0.27^{+}$ & n.s. & n.s. & n.s. \\
\hline Min temp. $\left({ }^{\circ} \mathrm{C}\right)$ & $\left(X_{2}\right)$ & n.s. & n.s. & $-0.35^{++}$ & n.s. & n.s. & n.s. & $-0.28^{+}$ & n.s. & n.s. & n.s. & n.s. & n.s. \\
\hline $\operatorname{Max}-\operatorname{Min}\left({ }^{\circ} \mathrm{C}\right)$ & $\left(\mathrm{X}_{3}^{2}\right)$ & $-0.40^{*}$ & $-0.30^{+}$ & $0.59^{* *}$ & $-0.36^{++}$ & n.s. & $-0.48^{* *}$ & $0.52^{* * 3}$ & $-0.38^{++}$ & $-0.40^{*}$ & $-0.47^{* *}$ & n.s. & $-0.28^{+}$ \\
\hline Evapor. $(\mathrm{mm} / \mathrm{d})$ & $\left(X_{4}\right)$ & $0.78^{* *}$ & n.s. & $0.32^{++}$ & $-0.67^{* * *}$ & $0.67^{* *}$ & $-0.51^{* * *}$ & n.s. & $-0.74^{* *}$ & n.s. & $-0.82^{* *}$ & $-0.49^{* *}$ & $-0.72^{* *}$ \\
\hline 0600 hours temp. $\left({ }^{\circ} \mathrm{C}\right)$ & $\left(X_{5}\right)$ & n.s. & $0.27^{+}$ & $-0.43^{*}$ & $-0.31^{+}$ & n.s. & n.s. & $-0.37^{++}$ & $-0.37^{++}$ & n.s. & n.s. & n.s. & n.s. \\
\hline 1800 hours temp. $\left({ }^{\circ} \mathrm{C}\right)$ & $\left(X_{6}\right)$ & n.s. & n.s. & n.s. & $-0.42^{*}$ & n.s. & n.s. & n.s. & $-0.37^{++}$ & n.s. & n.s. & n.s. & n.s. \\
\hline Sunshine $(\mathrm{h} / \mathrm{d})$ & $\left(X_{7}\right)$ & n.s. & n.s. & $0.38^{++}$ & n.s. & n.s. & n.s. & $0.32^{++}$ & n.s. & n.s. & $0.30^{+}$ & n.s. & $0.27^{+}$ \\
\hline Max humidity (\%) & $\left(X_{8}\right)$ & n.s. & n.s. & n.s. & $-0.64^{* *}$ & n.s. & n.s. & n.s. & $-0.71^{* *}$ & n.s. & $-0.60^{* *}$ & $-0.44^{*}$ & $-0.70^{* *}$ \\
\hline Min humidity (\%) & $\left(X_{9}^{8}\right)$ & n.s. & n.s. & $-0.54^{* *}$ & $0.69^{* * *}$ & $-0.32^{++}$ & $0.42^{*}$ & $-0.37^{++}$ & $0.72^{* *}$ & n.s. & $0.72^{* * *}$ & $0.40^{*}$ & $0.56^{* *}$ \\
\hline $\mathbf{R}^{2}$ & & 0.667 & 0.116 & 0.496 & 0.672 & 0.446 & 0.335 & 0.389 & 0.747 & 0.219 & 0.737 & 0.269 & 0.615 \\
\hline
\end{tabular}


ter ' $n=15$ for each quarter of each season') to calculate the relations.

Results obtained from the four quarters of the production stage for each season separately and for the combined data of the two seasons indicated that relationships varied markedly from one season to another. This may be due to the differences between the climatic factors in the two seasons as illustrated by its ranges and means shown in table I. For example, maximum temperature and surface soil temperature at 1800 hours did not show significant effects in the first season, while this trend differed in the second season.

Multiple linear regression equations obtained from data of the fourth quarter, for:

1) flower production:

$\mathrm{Y}=160.0+11.28 \mathrm{X}_{1}-4.45 \mathrm{X}_{3}-2.93 \mathrm{X}_{4}-5.05 \mathrm{X}_{5}$ $-11.3 \mathrm{X}_{6}-0.962 \mathrm{X}_{8}+2.36 \mathrm{X}_{9}$

with $\mathrm{R}^{2}=0.672$

2) boll production:

$\mathrm{Y}=125.4+13.74 \mathrm{X}_{1}-6.76 \mathrm{X}_{3}-4.34 \mathrm{X}_{4}-6.59 \mathrm{X}_{5}$ $-10.3 \mathrm{X}_{6}-1.25 \mathrm{X}_{8}+2.16 \mathrm{X}_{9}$

with $R^{2}=0.747$

3) boll retention ratio:

$\mathrm{Y}=81.93-0.272 \mathrm{X}_{3}-2.98 \mathrm{X}_{4}+3.80 \mathrm{X}_{7}-0.210 \mathrm{X}_{8}$ $-0.153 X_{9}$

with $\mathrm{R}^{2}=0.615$

The equation obtained from data of the second quarter of the production stage for boll retention ratio is:

$Y=92.81-0.107 X_{3}-0.453 X_{4}+0.298 X_{7}-$ $0.194 \mathrm{X}_{8}+0.239 \mathrm{X}_{9}$

with $\mathrm{R}^{2}=0.737$

$\mathrm{R}^{2}$ values for these equations ranged from 0.615 to 0.747 . It could be concluded that these equations may predict flower and boll production and boll retention ratio from the fourth quarter period within about $62-75 \%$ of its actual means. Therefore, these equations seem to have practical value.

Comparing table $I I I$ and $I V$, it can be seen that differences in $\mathrm{R}^{2}$ between the fourth quarter and the entire production period of the two seasons for
Table IV. Significant simple correlation values between the climatic factors and flower, boll production and boll retention ratio for combined data of the two seasons $(n=120)$.

\begin{tabular}{lcccc}
\hline Climatic factors & & Flower & Boll & Ratio \\
\hline Max temp. $\left({ }^{\circ} \mathrm{C}\right)$ & $\left(\mathrm{X}_{1}\right)$ & $-0.152^{++}$ & n.s. & n.s. \\
Min temp. $\left({ }^{\circ} \mathrm{C}\right)$ & $\left(\mathrm{X}_{2}\right)$ & n.s. & n.s. & n.s. \\
Max - Min $\left({ }^{\circ} \mathrm{C}\right)$ & $\left(\mathrm{X}_{3}\right)$ & $-0.259^{* * *}$ & $-0.254^{* * *}$ & n.s. \\
Evapor. $(\mathrm{mm} / \mathrm{d})$ & $\left(\mathrm{X}_{4}\right)$ & $-0.327^{* *}$ & $-0.429^{* *}$ & $-0.562^{* *}$ \\
0600 hours temp. $\left({ }^{\circ} \mathrm{C}\right)$ & $\left(\mathrm{X}_{5}\right)$ & n.s. & n.s. & n.s. \\
1800 hours temp. $\left({ }^{\circ} \mathrm{C}\right)$ & $\left(\mathrm{X}_{6}\right)$ & $-0.204^{*}$ & $-0.190^{++}$ & n.s. \\
Sunshine $(\mathrm{h} / \mathrm{d})$ & $\left(\mathrm{X}_{7}\right)$ & $-0.227^{*}$ & $-0.180^{++}$ & n.s. \\
Max humitiy $(\%)$ & $\left(\mathrm{X}_{8}\right)$ & n.s. & n.s & $-0.344^{* *}$ \\
Min humidity $(\%)$ & $\left(\mathrm{X}_{9}\right)$ & $0.303^{* *}$ & $0.364^{* * *}$ & $0.335^{* *}$ \\
$\mathbf{R}^{\mathbf{2}}$ & & $\mathbf{0 . 4 0 6}^{* *}$ & $\mathbf{0 . 4 2 2}^{* *}$ & $\mathbf{0 . 3 3 6}^{*}$ \\
& & & &
\end{tabular}

each of flower and boll production, and boll retention ratio were large $(0.266,0.325$ and 0.279 , respectively). These differences are sufficiently large to make a wide gap under a typical field sampling situation. This could be due to the high percentage of flower and boll production for the fourth quarter as shown in figures 3 and 4.

Equations obtained from data of the fourth quarter explained more variations in flower and boll production, and in boll retention ratio. Evaporation, humidity and temperature are the principal climatic factors that govern cotton flower and boll production during the fourth quarter, since they were most strongly correlated with the dependent variables studied (table III).

Evaporation, which seems to be the most important climatic factor, had a negative significant relationship, which means that high evaporation ratio reduces significantly flower and boll production. This may be due to plant water deficit when evaporation increases.

Maximum temperature, temperature magnitude and maximum humidity also showed a negative significant link with fruiting production, which indicates that these climatic variables have a determinable effect upon Egyptian cotton fruiting production.

Minimum humidity was positively highly correlated in most quarter periods for flower and boll 
production, and boll retention ratio. This means that an increase in this factor will increase both flower and boll production.

Maximum temperature is sometimes positively and sometime negatively linked to boll production (table III). This erratic correlation may be due to the variations in the values of this factor between the quarters of the production stages, as shown from its range and mean values (table I).

The optimum temperature range for biochemical and metabolic activities of plants (a temperature range that permits normal enzyme functions in plants) has been defined as a thermal kinetic window (TKW) [3]. Plant temperatures either above or below the TKW result in stress that limits growth and yield. The TKW for cotton growth proposed by Burke et al. [3] is $23.5-32{ }^{\circ} \mathrm{C}$, with an optimum temperature of $28^{\circ} \mathrm{C}$. Biomass production is directly related to the amount of time that foliage temperatures are within the TKW. Productivity of cotton, therefore, is strongly influenced by the relationship between the plant's TKW and the temperature the crop experiences during the growing season.

Burke et al. [2] pointed out that the usefulness of the $27.5{ }^{\circ} \mathrm{C}$ midpoint temperature of the TKW of cotton as a baseline temperature for a thermal stress index (TSI) was investigated in field trials on cotton cv. Paymaster 104. This biochemical baseline and measurements of foliage temperature were used to compare the TSI response with the cotton field performance. Foliage temperature was measured with hand-held $4{ }^{\circ} \mathrm{C}$ field of view IR thermometer while plant biomass was measured by destructive harvesting. The biochemical based TSI and the physically based crop water stress index were highly correlated $\left(r^{2}=0.92\right)$ for cotton across a range of environmental conditions.

Guo et al. [11], in a field experiment with different irrigation treatments conducted at a humid and an arid area in Texas with cotton cv. DPL-50, found that plant size and yield were lower in humid areas than in arid areas. Under arid conditions, high vapour pressure deficit results in high transpiration rate, low leaf water potential and low leaf temperature. Reddy et al. [15] found in controlled environmental chambers that pima cotton cv. S-6 produced less total biomass at $35.5^{\circ} \mathrm{C}$ than at $26.9{ }^{\circ} \mathrm{C}$ and no bolls were produced at the higher temperature of $40{ }^{\circ} \mathrm{C}$. This confirms the results of this study as maximum temperature showed a negative significant relationship with production variables in the fourth quarter period of the production stage. Zhen Jin Zhong [20] found that the most important factors decreasing cotton yields in Huangchuan County, Henan were low temperatures in spring, high temperatures and pressure during summer and the sudden fall in temperature at the beginning of autumn. Measures to increase yields included the use of the more suitable high-oil cotton cultivars, which mature early, and choosing sowing dates and spacing so that the best use was made of the light and temperature resources available. Reddy et al. [16] observed that when cotton cv. DPL-51 was grown in controlled environments (SRAR units) with natural solar radiation, flower and fruit production increased slightly as temperature increased, but fruit retention was very low or non-existent at ambient plus 5 or $7{ }^{\circ} \mathrm{C}\left(31.3\right.$ and $\left.33{ }^{\circ} \mathrm{C}\right)$. It was concluded that cotton will be severely damaged by temperatures above those presently found during midsummer in the cotton belt in the USA.

It may appear that the grower would have no control over boll shedding induced by high temperature, but this is not necessarily the case. If he can irrigate, he can exert some control over temperature since transpiring plants have the ability to cool themselves by evaporation. The leaf and canopy temperatures of drought-stressed plants can exceed those of plants with adequate quantity of water by several degrees when air humidity is low [6]. The grower can partially overcome the adverse effects of high temperature on net photosynthesis by spacing plants to adequately expose the leaves. Irrigation may also increase photosynthesis by preventing stomatal closure during the day. Adequate fertilization is necessary for maximum rates of photosynthesis. Finally, cultivars appear to differ in their heat tolerance [7]. Therefore, the grower can minimize boll abscission where high temperatures occur by selecting a heat-tolerant cultivar, planting date management, applying an adequate fertilizer, planting or thinning for optimal plant spacing, and irrigating as needed to prevent drought stress. 


\section{Conclusion}

This investigation identified the important climatic factors (evaporation, humidity and temperature) affecting flower boll production in Egyptian cotton, as indicated by their highly significant simple correlation values. The regression equations proved to have a good predictive value as shown from their relatively high values for the coefficient of multiple determination $\left(\mathrm{R}^{2}\right)$. In addition, these equations seem to be agriculturally meaningful as they have reasonable regression coefficients, and explain as much flowering and boll response variation as possible. Also, from these data, it could be concluded that the fourth quarter period of the production stage is the most appropriate and usable production time to collect data for determining efficient prediction equations for cotton flower and boll production in Egypt, and making valuable recommendations.

\section{References}

[1] Barker G.L., Hatfield J.L., Wanjura D.F., Influence of wind on cotton growth and yield, Trans. ASAE, Am. Soc. Agric. Eng. 32 (1989) 97-104.

[2] Burke J.J., Hatfield J.L., Wanjura D.F., A thermal stress index for cotton, Agron. J. 82 (1990) 526-530.

[3] Burke J.J., Mahan J.R., Hatfield J.L., Crop specific thermal kinetic windows in relation to wheat and cotton biomass production, Agron. J. 80 (1988) 553-556.

[4] Cady F.B., Allen D.M., Combining experiments to predict future yield data, Agron. J. 64 (1972) 211-214.

[5] Draper N.R., Smith H., Applied Regression Analysis, John Wiley and Sons, Ltd, New York, 1966.

[6] Ehrler W.L., Cotton leaf temperatures as related to soil water depletion and meteorological factors, Agron. J. 65 (1973) 404-409.

[7] Fisher W.D., Heat induced sterility in upland cotton, Proc. 27th Cotton Improvement Conf., 1975, p. 85.

[8] Gipson J.R., Temperature effects on growth, development and fiber properties, in: Mauney J.R., Stewart J.M. (Eds.), Cotton Physiology, Cotton Foundation, Memphis, TN, 1986, p. 47-56.
[9] Gipson L.R., Joham H. E., Influence of night temperature on growth and development of cotton (Gossypium hirsutum L.): I. Fruiting and boll development, Agron. J. 60 (1968) 292-295.

[10] Guinn G.A., Abscission of cotton floral buds and bolls as influenced by factors affecting photosynthesis and respiration, Crop Sci. 14 (1974) 291-293.

[11] Guo Y., Landivar J.A., Hanggeler J.C., Moore J., Response of cotton leaf water potential and transpiration to vapor pressure deficit and salinity under arid and humid climate conditions, in: Proceedings Beltwide Cotton Conferences, 5-8 January, San Diego, California, USA. Memphis, USA, National Cotton Council, 1994, pp. 1301-1308.

[12] Hodges H.F., Reddy K.R., McKinion J.M., Reddy V.R., Temperature effects on cotton, BulletinMississippi Agricultural and Forestry Experiment Station, no. 990, 1993, 15 pp.

[13] Miller J.K., Krieg D.R., Paterson R.E., Relationship between dryland cotton yields and weather parameters on the Southern High Plains, in: Proceedings Beltwide Cotton Conferences, 9-12 January, Nashville, TN, USA, Memphis, USA, National Cotton Council, 1996, pp. 1165-1166.

[14] Ramey H.H., Stress influence on fiber development, in: Mauney J.R., Stewart J.M. (Eds.), Cotton Physiology, Cotton Foundation, Memphis, TN, 1986, pp. 351-360.

[15] Reddy K.R., Hodges H.F., McKinion J.M., Carbon dioxide and temperature effects on pima cotton growth, Agric., Ecosyst. Environ. 54 (1995) 17-29.

[16] Reddy K.R., Hodges H.F., McKinion J.M., Can cotton crops be sustained in future climates?, in: Proceedings Beltwide Cotton Conferences, 9-12 January, Nashville, TN, USA, Memphis, USA, National Cotton Council, 1996, pp. 1189-1196.

[17] Reddy V.R., Reddy K.R., Acock B., Carbon dioxide and temperature interactions on stem extension, node initiation, and fruiting in cotton, Agric., Ecosyst. Environ. 55 (1995) 17-28.

[18] SAS Institute, Inc., SAS User's Guide: Statistics. 5th ed. SAS Inst., Inc. Cary, NC, 1985.

[19] Winter K., Koniger M., Dry matter production and photosynthetic capacity in Gossypium hirsutum L. under conditions of slightly sub-optimal leaf temperatures and high levels of irradiance, Oecologia 87 (1991) 190-197.

[20] Zhen Jin Zhong, The causes of low cotton production in Huanghchuan County and measures to increase production, Henan Mongye Kexue 2 (1995) $5-6$. 